\title{
Troels-Lund og A. D. Jørgensen
}

\section{Af Henrik Gjøde Nielsen}

Mellem de to fremtrædende historikere Troels-Lund og A. D. Jørgensen var der kun fă personlige kontakter - og alligevel var de på mange måder åndeligt beslægtede. Cand.phil. Henrik Gjøde Nielsen trækker her - i 150-året for deres fødsel - paralleller mellem de to mænd, som begge var dybt præget af Danmarks nederlag i 1864.

Aret 1864 medførte store tab for Danmark; tab, som man i de følgende år søgte at afhjælpe ved at styrke det beskårne land, både fysisk og åndeligt. På det fysiske område søgte man med hedeopdyrkningen at følge Enrico Mylius Dalgas’ devise om, at hvad udad tabes skal indad vindes, mens man på det åndelige område, bl.a. $\mathrm{i}$ historievidenskaben, kan se en voldsom udvikling $\mathrm{i}$ den sidste halvdel af det 19. århundrede.

To centrale skikkelser i dansk historieskrivning i denne periode er kulturhistorikeren Troels-Lund, og den der blev Sønderjyllands historiker, nemlig A. D. Jørgensen. De to mænds livsværk er bl.a. et udtryk for, at man ikke havde glemt danskerne i det besatte Sønderjylland.

På trods af store forskelle mellem de to mænds livsforløb er der også væsentlige lighedspunkter mellem Troels-Lund og A. D. Jørgensen; lighedspunkter, man ikke tidligere har været opmærksom på. Begges virke og selvopfattelse var tæat knyttet til begivenhederne i 1864, hvilket blot er et af de punkter, på hvilke man kan betragte et vist skæbnefællesskab mellem de to historikere.

Det er ikke hensigten her at give en udtømmende redegørelse for TroelsLunds og A. D. Jørgensen's liv og virke, men dels nærmere at bestemme dette skæbnefællesskab, dels at præsentere de enkelte kontakter og skriftlige fremstillinger, der angiver de elementer, der knytter de to historikere sammen.

Forinden vil en kort præsentation af de to forfattere og deres forbindelse med året 1864 dog være på sin plads.

Adolf Ditlev Jørgensen blev født d. 11. juni 1840 i Graasten, og døde d. 5. oktober 1897 i København; A. D. Jørgensen kom fra en dansksindet, sønderjysk slægt. ${ }^{1}$ I 1859 tog A. D. Jørgensen realeksamen i Flensborg, hvorefter fulgte nogle studieår i København, dog uden at der var tale om et egentligt embedsstudium. ${ }^{2}$ Alligevel blev A. D. Jørgensen ansat som lærer ved latinskolen i Flensborg; en stilling, som han måtte forlade ved besættelsen af Slesvig 
i $1864 .{ }^{3}$ Fra 1869 ansattes han i Kongerigets Arkiv i København, blev i 1883 Gehejmearkivar, og i 1889 Rigsarkivar. ${ }^{4}$ Som sådan var A. D. Jørgensen den ledende kraft i den organisering af dansk arkivvæsen, som vi også kender i dag, med et rigsarkiv og dengang tre, nu fire, landsarkiver, samtidig med, at han udfoldede en rig forfatter- og forskningsvirksomhed, ${ }^{5}$ der gjorde ham til en af de mest fremtrædende skikkelser i moderne dansk historievidenskab, i den kildekritiske skole. Det er her vigtigt at mærke sig, at A. D. Jørgensen ikke var faguddannet historiker.

A. D. Jørgensen's tidlige død i 1897 betød, at han ikke oplevede genforeningen i 1920, og dermed afklaringen på det spørgsmål, der havde så stor betydning for hans liv og virke. Samtidig mistede dansk historievidenskab en personlighed, der forstod at samle kritisk forskning og kunstnerisk fremstilling på en sjælden måde.

Troels Frederik Troels-Lund blev født i København d. 5. september 1840, d.v.s. samme år som A. D. Jørgensen, og døde samme sted d. 12. februar 1921. ${ }^{6}$ I modsætning til A. D. Jørgensen nåede Troels-Lund således at opleve genforeningen.

Troels-Lund var af en velstående, nationalsindet, borgerlig familie, der blev præget af både Den forste Slesvigske Krig 1848-1850, og, ikke mindst, af Den anden Slesvigske Krig i 1864. ${ }^{7}$ Troels-Lund mistede i 1864 sin broder Peter Lund, der var med i krigen som menig. ${ }^{8}$ D. 29. juni 1864 deltog Peter Lund i kampen nord for Kær på Als; han blev såret af en kugle, der trængte gennem den ene lunge og ryggen, og bragt til lazarettet på Sandbjerg Slot i Sundeved, hvortil Troels-Lund rejste fra København for at være ved sin broders side i dennes sidste dage. ${ }^{9}$ Peter Lund døde d. 18. juli $1864 \mathrm{og}$ blev begravet på Ulkebøl Kirkegård på Als. ${ }^{10}$ Som for A. D. Jørgensen blev 1864 et katastrofeår for Troels-Lund. Udadtil p.g.a. det nationale nederlag, indadtil p.g.a. broderens død.

Mens A. D. Jørgensen ikke tog nogen embedseksamen, tilskyndede begivenhederne i 1864 tilsyneladende Troels-Lund til at samle sig om et embedsstudium. I 1866 tog Troels-Lund teologisk embedseksamen, uden at denne nogensinde kom i anvendelse, og i 1871 forsvarede Troels-Lund en afhandling om Sokrates for den filosofiske doktorgrad." Skønt Troels-Lund således, lige som A. D. Jørgensen, ikke var faguddannet historiker, blev han i 1871 ansat ved Gehejmearkivet, ${ }^{12}$ og det var her de to mænds veje første gang mødtes.

Der er intet der tyder på, at Troels-Lund og A. D. Jørgensen havde et tæt, personligt forhold til hinanden. Der foreligger ingen egentlig brevveksling mellem de to, som tilfældet f.eks. er mellem Troels-Lund og Georg Brandes. 
A.D.Jergensen fotograferet omkring 1870.

Dansk Centralbibliotek for Sydslesvig.

Imidlertid ved vi, at Troels-Lund og A. D. Jørgensen har mødt hinanden, nemlig i Rentekammerarkivet. Troels-Lund har i sin skildring af dette møde, en dag $i$ begyndelsen af 1870 erne, ${ }^{13}$ givet en smuk og rammende karakteristik af A. D. Jørgensen; en karakteristik, der angiver både den kunstneriske, eller poetiske, og den forskermæssige side af A. D. Jørgensen.

Efter at have beskrevet, hvorledes Troels-Lund betragtede arkivmedarbejdernes forskellige måde at behandle arkivalier på, formulerer Troels-Lund sit første indtryk af A. D. Jørgensen således:

"I det samme aabnedes Døren og ind traadte en mig ubekendt ung Mand, slank og dog kraftigt bygget, lyshaaret, blaaøjet, med en usædvanlig rank Holdning og Hovedet ligesom standset $i$ at bøje sig. Under hver Arm bar han en Stabel Arkivsager, paa en egen nænsom, kyndig Maade som en Gartnerelev et Par store Urtepotter med Blomster, han er opsat paa at sørge for. Uvilkaarligt blev jeg opmærksom paa den unge Mand og fulgte ham med øjnene. Da han kom mig nær, saa jeg et Ansigt, hvori det intelligente halvvejs traadte tilbage for noget drømmende, bly, næsten blufærdigt, men tillige en Mund 
med smalle Laber, der med eet kunde strammes og forme det hele Udtryk, naar han talte, til klar, anspændt Interesse.

(...)

Den unge Mand var A. D. Jørgensen. ${ }^{14}$

Efter dette første møde var der for så vidt grund til at antage, at et personligt venskab mellem de to mænd kunne have udviklet sig. Den personlige sympati synes at have været til stede. Når et sådant venskab imidlertid ikke udviklede sig, må det tilskrives Troels-Lund og A. D. Jørgensen's forskellige udvikling og karrierer. A. D. Jørgensen blev rigsarkivar og tillige en central skikkelse i den kildekritiske skole og desuden gennem sin historieskrivning Sønderjylland's historiker, mens Troels-Lund med sit monumentale hovedværk, »Dagligt Liv i Norden i det sekstende Aarhundrede«, lagde grunden til dansk kulturhistorisk videnskab.

Netop »Dagligt Liv i Norden i det sekstende Aarhundrede« blev, på sin vis indirekte, anledning til den næste kontakt, der lader sig spore mellem TroelsLund og A. D. Jørgensen.

Troels-Lund's hovedværk omhandlede primært renæssancemenneskets klædedragt, boligforhold, borddækning, spisevaner o.s.v., eller kort sagt: Dagliglivets historie. En af hensigterne med dette værk var, lige som for en del af A. D. Jørgensen's forfatterskab, på historiens område at vinde indad, hvad udad var tabt. Troels-Lund's emneområde var nyt land, der blev gjort frugtbart under historievidenskabens plov; dette var imidlertid ikke et synspunkt, der deltes af samtiden, og da slet ikke fra tysk side.

I sidste del af 1880 'erne og første del af 1890'erne måtte Troels-Lund se sit værk udsat for heftige angreb; angreb, som Troels-Lund ikke tog til genmæle mod. Men da den preussiske professor Dietrich Schäfer i 1893 i sin bog "Geschichte von Dänemark" fremhævede Troels-Lund's værk som et typisk udtryk for en stagnerende nation, fra hvilken man ikke kunne forvente at se bemærkelsesværdige opgaver udført, og tillige anfægtede Danmark's nationale eksistensberettigelse, tog Troels-Lund endelig til genmæle. ${ }^{15}$ Schäfer betegnede på det nærmeste Troels-Lund's værk som et tegn på nationens hendøen, og hævdede, at en sådan nations "moralske " pligt var at lade sig opsluge af en ekspanderende, »moralsk « stærkere nation, d.v.s. Tyskland, og hævdede videre, at historievidenskabens egentlige genstandsområde måtte være disse sejrende nationers politiske historie, og ikke noget så underordnet som historien om, hvordan mennesket levede og tænkte, f.eks. i renæssancen. I sit svar, Kulturhistorie«, 1894, argumenterede Troels-Lund dels for dagliglivets berettigelse som genstand for historisk forskning, dels for, at staternes moral er af 
yderst tvivlsom værdi, da ordet "Krig« ophæver alle hensyn og forpligtelser og giver staterne en meget lav "moral «, der ikke kendes fra andre menneskelige forhold. Med andre ord: At en nation med vold kan undertvinge en anden, er ikke ensbetydende med "moralsk ret«.

Schäfer's holdning kunne naturligvis "retfærdiggøre" den tyske okkupation i 1864, og blev da også senere anvendt i nazistisk tjeneste. Når Troels-Lund ikke tidligere havde forsvaret sig over for de talrige angreb, så skyldtes det, at disse udelukkende var rettet mod hans værk. Da angrebene nu også anfægtede Danmark's eksistensberettigelse, følte Troels-Lund, at han måtte tage til genmæle. Dette gjorde han så skarpt, at konklusionen bl.a. måtte blive, at Tyskland med vold havde taget en del af Danmark.

For de mange i samtiden, der også var personligt og nationalt mærkede af 1864, satte Troels-Lund's skrift »Om Kulturhistorie« tingene i perspektiv og gav den nationale selvfølelse en tiltrængt åndelig støtte. Dette kommer bl.a. til udtryk i den eneste direkte skriftlige kontakt mellem Troels-Lund og A. D. Jørgensen, jeg har været i stand til at finde. I et brev, dateret d. 2. januar 1894, skriver A. D. Jørgensen til Troels-Lund:

"Hr. professor dr. T. Lund! - Tillad mig at sende Dem en hjertelig tak for Deres svar til professor Schäfer, der så smukt og træffende hævder tanker og følelser, som vi alle nærer.

Med glædeligt nytår ærbødigst

A. D. Jørgensen. $\ll^{16}$

Denne kontakt er sammen med de to historikeres møde i Rentekammerarkivet den eneste direkte berøring mellem de to mænd, der lader sig spore. Heller ikke i 1894 synes deres fælles udgangspunkt, og deres fælles tilknytning til 1864 , at have ført til nærmere kontakt.

Tre år senere, i 1897, døde A. D. Jørgensen.

Fire år efter A. D. Jørgensen’s død, i 1901, udkom hans efterladte manuskript, "En Redegørelse for min Udvikling og mit Forfatterskab «. ${ }^{17}$ Denne bog affødte artiklen »A. D. Jørgensen «, ${ }^{18} \mathrm{i}$ hvilken Troels-Lund for første og eneste gang offentligt og på skrift formulerede sig om en af sine danske fagfæller. ${ }^{19}$ Det interessante ved denne artikel er, at samtidig med at Troels-Lund skriver om A. D. Jørgensen, skriver han også, sandsynligvis ubevidst, om sig selv, således at lighedspunkterne mellem de to mænd mere præcist lader sig bestemme.

Når Troels-Lund skrev om netop A. D. Jørgensen, må det efter min opfattelse skyldes, at også Troels-Lund har følt et vist skæbnefællesskab mellem sig 
selv og A. D. Jørgensen, de store forskelle i faglig løbebane til trods. Som nævnt var ingen af de to faguddannede historikere, begge var nationalt og personligt mærkede af nederlaget i 1864, og begge betragtede deres forfatterskab som et udslag af en trang til at gavne det beskårne fædreland; for A. D. Jørgensen's vedkommende specielt hjemstavnen Sønderjylland. ${ }^{20}$ Således kan Troels-Lund's "Dagligt Liv i Norden i det sekstende Aarhundrede«, der første gang udkom i perioden 1879-1901, og A. D. Jørgensen's »40 Fortællinger af Fædrelandets Historie«, der udkom første gang i 1882, begge opfattes som udtryk for det samme ønske: En gave, til trøst og styrke for det danske folk, blot med den forskel, at „Dagligt Liv i Norden« bevægede sig på det nationale niveau, mens "40 Fortællinger af Fædrelandets Historie« koncentrerede sig om forhold i grænseegnene, og havde som intention at være "lommehejskole for hjemmene i Nordslesvig «. ${ }^{21}$ Endelig var arkivarbejdet for både Troels-Lund og A. D. Jørgensen den konkrete indgang til det historiske arbejde.

Ud over de ovennæunte elementer er der yderligere fire fælles karakteristika, der lader sig uddrage af Troels-Lund's artikel om A. D. Jørgensen.

Efter at have redegjort for sit første møde med A. D. Jørgensen i Rentekammerarkivet - en redegørelse, der er citeret ovenfor - og ganske kort angivet hovedtrækkene i A. D. Jørgensen's biografi, ${ }^{22}$ fremhæver Troels-Lund det første fælles træk, nemlig ensomheden. Troels-Lund skriver, at A. D. Jørgensen's livsopgave betød, at han blev en ensom mand, uden venner og fortrolige. ${ }^{23}$ Troels-Lund nævner det, naturligvis, ikke eksplicit, men ensomheden blev dog også ham selv til del, i form af tiltagende isolation fra 1870'erne, og resten af livet. $^{24}$

Det andet fælles punkt, der kan udledes af A. D. Jørgensen's »En Redegørelse for min Udvikling og mit Forfatterskab«, og Troels-Lund's artikel om A. D. Jørgensen, gælder de to mænds interesse for Sokrates. Troels-Lund fremhæver A. D. Jørgensen's personlige fremtidsideal, når de øvrige forpligtelser var indfriet, nemlig at sysle med filosofi; et fremtidsideal, der af A. D. Jørgensen formuleres som interesse for Sokrates, hvilket, ifølge Troels-Lund, også er udtryk for en del af A. D. Jørgensen's selvforståelse. ${ }^{25}$ Som nævnt disputerede Troels-Lund på en afhandling om Sokrates, så også på det filosofiske område er der et vist interessesammenfald.

Det tredie punkt, på hvilket man aner, at Troels-Lund har følt et sammenfald, er i A. D. Jørgensen's sprogbehandling, der ikke blot satte A. D. Jørgensen i stand til både at give kritisk sondring og formning af helhedsbilleder en let tilgængelig form, men også, i A. D. Jørgensen's bedste fremstillinger, at opnå en sprogligt enestående virkning, $i$ hvilken det er som om folkeånden selv taler. ${ }^{26}$ Med andre ord: For A. D. Jørgensen som for Troels-Lund var fremstillingens "almenfattelighed" af meget væsentlig betydning, hvilket rimeligvis 


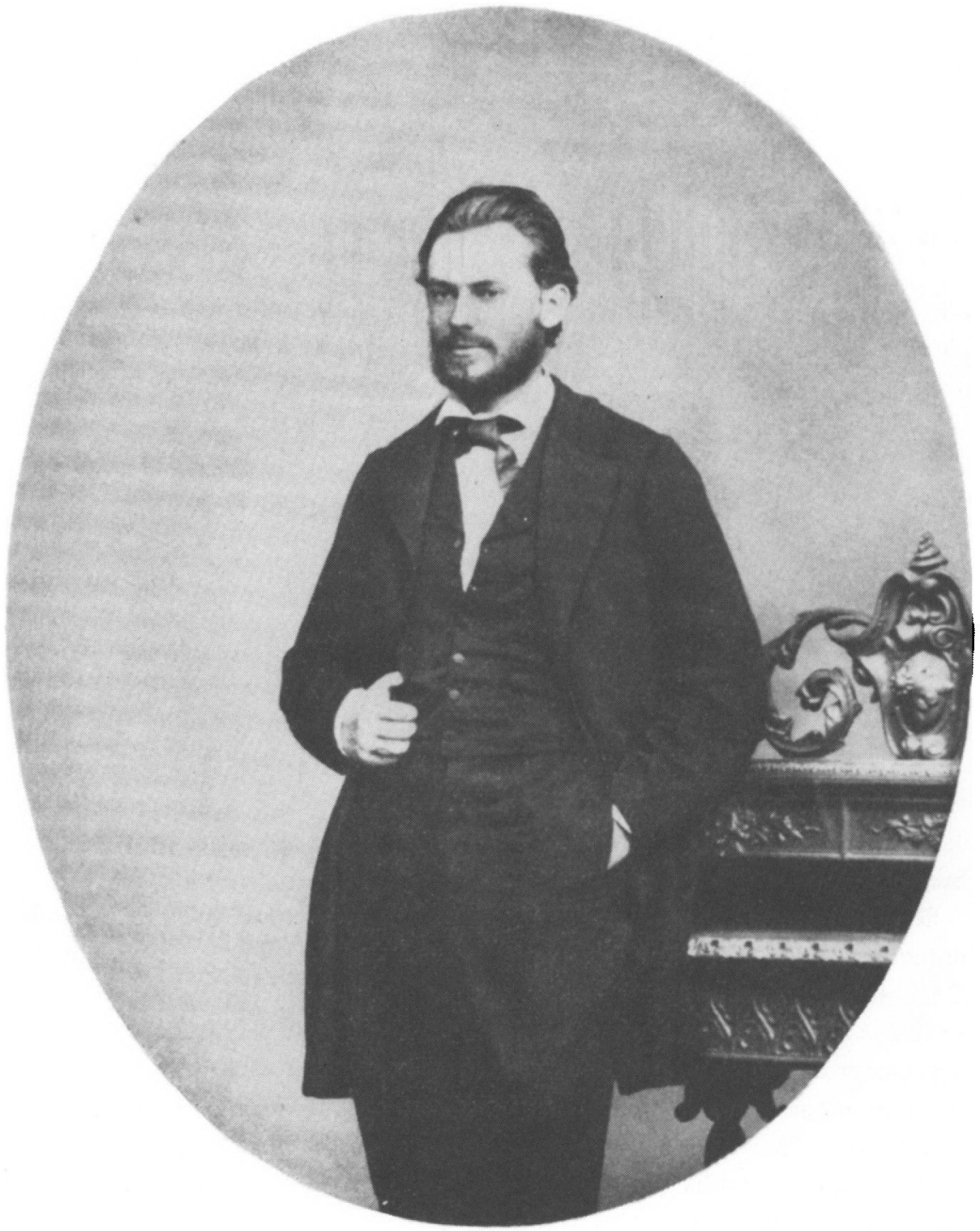

Troels-Lund fotograferet sidst i 1870'erne. Gengivet efter Troels-Lund: Dagligt Liv $i$ Norden $i$ det sekstende Arhundrede, 6. udg., Gyldendal 1968 bd. 1 s. 21.

netop skal ses i sammenhæng med begges valg af livsopgave, og, ikke mindst, valgets baggrund.

Denne fælles baggrund lader Troels-Lund, som det fjerde fælles træk, A. D. 


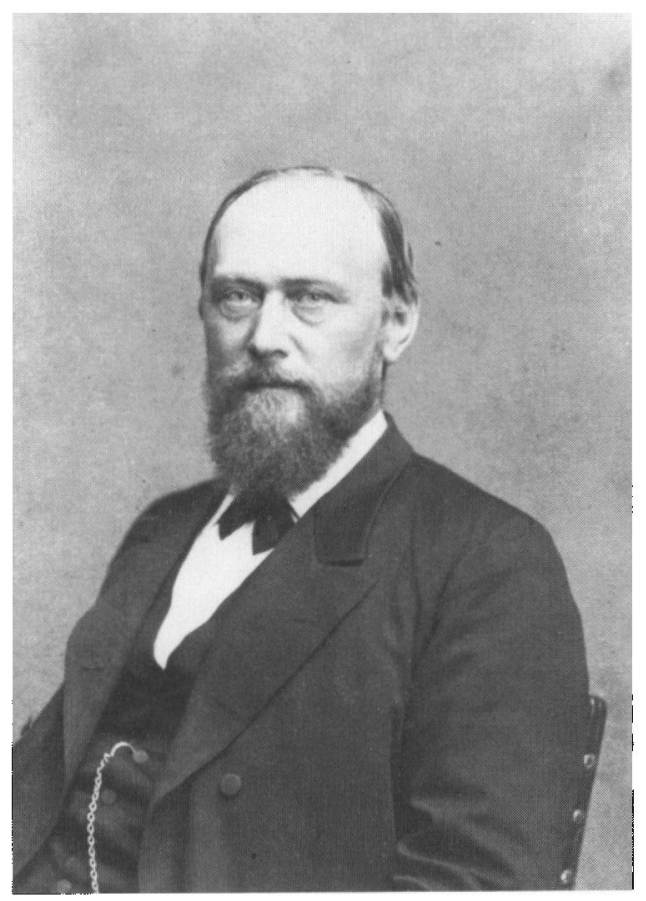

A.D.Jorgensen fotograferet omkring I885.

Dansk Centralhibliotek for Sydslesvig.

Jørgensen selv udtrykke, i det korte og koncise svar på spørgsmålet om, hvorledes han blev historiker: "Fordi jeg oplevede $1864 \ll{ }^{27}$

Trods forskel i opvækst, dannelse og løbebane er det derfor rimeligt at antage, at A. D. Jørgensen var den blandt de danske historikere, som TroelsLund følte sig nærmest beslægtet med, hvilket for det første kan forklare artiklens tilblivelse, og for det andet de elementer i denne, som her er fremhævet. Der er tale om et slægtskab, der ikke så meget drejer sig om rigsarkivaren, men om historikeren, d.v.s. historieskriveren, og sønderjyden A. D. Jørgensen. Det er ifølge Troels-Lund om historieskriveren A. D. Jørgensen, mindet længst vil holde sig, værnet af det danske sprog. ${ }^{28}$

Hvor tæt A. D. Jørgensen, ud fra de samme betragtninger, har følt sig knyttet til Troels-Lund, er svært at sige. A. D. Jørgensen har ikke selv formuleret sig om dette forhold. Skønt Troels-Lund og A. D. Jørgensen givet har været uenige i mangt og meget, for så vidt angår samtidshistoriske, forsvarspolitiske og historievidenskabelige forhold m.v., så er begges skæbne og livsbane dog i den grad knyttet til Sønderjylland's skæbne og året 1864, at det er sandsynligt at antage, at også A. D. Jørgensen har følt et vist skæbnefællesskab med 
Troels-Lund. A. D. Jørgensen’s tidligere citerede brev indicerer da også noget sådant.

Den manglende personlige kontakt mellem de to mænd kan muligvis for en del forklares ved A. D. Jørgensen's fremtrædende rolle i den kildekritiske skole, der blev betragtet som "rigtig" historievidenskab; en betegnelse, man $i$ samtiden vægrede sig ved at give Troels-Lund's arbejde.

Året 1990 er 150-året for både Troels-Lunds og A. D. Jørgensen's fødsel. Endnu et lighedspunkt mellem de to er den store, folkelige gennemslagskraft, deres værker havde, og har. "Dagligt Liv i Norden« og »40 Fortællinger« er siden udgivelsen blevet optrykt igen og igen. Troels-Lund er fortsat dagliglivets historiker, lige som A. D. Jørgensen er Sønderjyllands historiker.

Naturligvis har historievidenskaben udviklet sig, og er kommet til nye, andre, og muligvis rigtigere resultater, end Troels-Lund og A. D. Jørgensen kom til. Alligevel læses de to gamle historikere stadig; deres værk glemmes for en stund, genopdages på ny, og er fortsat et bekendtskab værd.

Når både Troels-Lund og A. D. Jørgensen er enestående skikkelser i dansk historievidenskab, må det ikke mindst skyldes, at for dem var historie ikke blot kritisk forskning og streng videnskabelighed; det var også kunstnerisk fremstilling af resultaterne, bevidst skrevet for en bred og stor læserskare.

Det skyldes historiekunsten, den levende og fængende fremstilling, at de to mænds arbejder fortsat læses, diskuteres og analyseres, og det er p.g.a. historiekunsten, med Troels-Lund's ord, at mindet om Troels-Lund og A. D. Jørgensen vil holde sig.

\section{LITTERATURLISTE}

Borup, Morten (udg.): Georg og Edv. Brandes. Brevveksling med nordiske Forfattere og Videnskabsmand. Bd. I. 1939.

Jergensen, A. D.: En Redegørelse for min Udvikling og mit Forfatterskab. 1901.

Jørgensen, A. D.: 40 Fortallinger af Fædrelandets Historie. 1981.

Jørgensen, Harald: A. D. Jørgensens Breve. 1939.

Nielsen, Henrik Gjøde: Kulturhistorien \& Historiekunsten. En analyse af Troels-Lund's forfatterskab, 1859-1921. Specialeathandling. Historiestudiet. Aalborg Universitetscenter, 1988.

Nielsen, Henrik Gjøde: Et overset arbejde af Troels-Lund. Bidrag til dansk kulturhistories historiografi. I: Fortid og nutid, 1989. Bd. XXXVI, hefte 2. S. 113-120.

Olrik, H.: Jørgensen (, Adolf Ditlev). I: Salmonsens Konversationsleksikon. Anden Udgave. 1922. Bd. XIII. S. 322-324.

Rerup, Lorenz: A. D. Jorgensen. 1965.

Rerup, Lorenz: Forord. I: A. D. Jørgensen: 40 Fortællinger af Fædrelandets Historie. 1981. S. 7-9.

Troels-Lund, Troels Frederik: Om Kulturhistorie. 1894. I: Troels-Lund: Dagligt Liv i Norden i det sekstende Aarhundrede. Bd. I, s. I-XL. Fjerde Udgave. 1914.

Troels-Lund, Troels Frederik: A. D. Jørgensen. I: Lllustreret Tidende. Nr. 50. 42. Bd. D. 15. September, 1901. S. 783-784. 
Troels-Lund, Troels Frederik: A. D. Jørgensen. I: Troels-Lund: Historiske Fortællinger, Tider og Tanker. IV. Bind, VIII. Bog. 1912. S. 265-274.

Tandrup, Leo: Troels-Lund, Troels. I: Dansk Biografisk Leksikon. 3. udg. 1984. 15. bd. S. 30-36.

\section{NOTER OG HENVISNINGER}

1. Olrik, 1922, s. 322.

2. op.cit., s. 323 .

3. ibid.

4. ibid.

5. ibid.

6. Nielsen, 1988 , s. 24 , s. 35 .

7. op.cit., s. 24 , s. $26-27$.

8. op.cit., s. 26.

9. op.cit., s. 27.

10. ibid.

11. op.cit., s. 28.

12. ibid.

13. Troels-Lund, 1912, s. 265.

14. op.cit., s. 266-267.

15. En nærmere redegørelse for hele forløbet findes hos Nielsen, op.cit., s. 82-100. Se desuden TroelsLund, 1914.

16. Jørgensen, 1939, s. 344. Troels-Lund udbyggede senere sine synspunkter fra "Om Kulturhistorie«, jvf. Nielsen, op.cit., s. 123-128; Nielsen, 1989, s. 113-120.

17. I Sønderjyske Årbøger, 1953, 2. halvbind, findes i Troels G. Jørgensen's afhandling, "A. D. Jørgensen, skildret af en søn«, et udeladt stykke af redegørelsen, jvf. Rerup, 1965, s. 135.

18. Troels-Lund, 1901; Troels-Lund, op.cit., 1912.

19. Undtagelsen fra denne regel er en tidlig. rent faglig polemik, jvf. Nielsen, op.cit., 1988, s. 50-51.

20. Troels-Lund, op.cit., 1912, s. 268.

21. Rerup, 1981, s. 7-8.

22. Troels-Lund, op.cit., s. 267-268.

23. op.cit., s. 268.

24. Tandrup, 1984, s. 32. Borup, 1939, s. 374-376.

25. Troels-Lund, op.cit., s. 268.

26. op.cit., s. 269-270.

27. op.cit., s. 274.

28. ibid. 